\title{
VIEWPOINT
}

\section{The Biennial of Public Space in Rome. From the Charter of Public Space to the Post-Habitat III Agenda}

\section{Pietro Garau}

University of Rome "La Sapienza" | INU - Italian Institute of Urban Planners pietro.garau@gmail.com

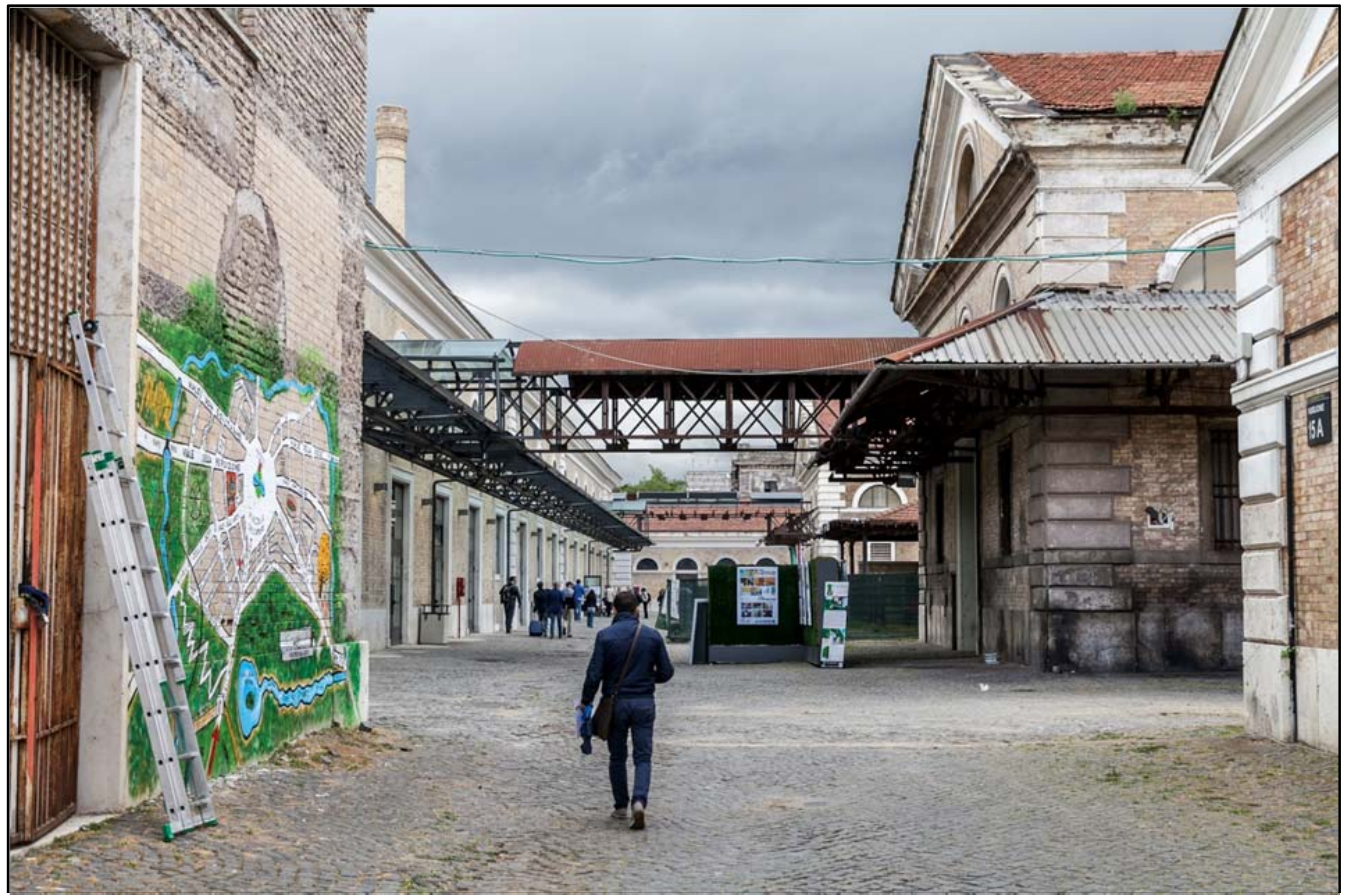

Fig. I. Main location of the Biennial of Public Space at Rome's Third University (Roma Tre), Testaccio neighbourhood. Picture by Elettra Giulia Bastoni.

In May 20I3, the Biennial of Public Space adopted the "Charter of Public Space". The idea, presented at a well-attended event at the 2012 World Urban Forum, was to seek a universally acceptable definition of "public space" and to lay down a few basic principles that could be shared and implemented everywhere.

Emphasizing process over output is one of the most common platitudes of contemporary discourse. Yet, the method adopted for putting together this document is worthy of mention. First, comments were sought from a small group of researchers and practitioners constituting the Biennale's "Scientific Committee". On that basis, a team composed by the author of this article and by two other Biennale curators coming from different academic and professional backgrounds, Lucia Lancerin and Marichela Sepe, put together the Charter's "loom": a loose texture whose purpose, once vetted by a much larger group of contributors, was to constitute a framework for a more detailed fabric. The loom consisted of a draft definition of public space and of three motifs to be developed at a later stage - the creation, management 
and enjoyment of public space. In addition, the question "if public space is so clearly important for our quality of life, why is it not much better and more abundant than it is now?" led to the enumeration of the obstacles to the creation, management and enjoyment of public space in our cities.

The so-called "social networks" were at a much more rudimentary stage of development than they are today, and this might perhaps be the reason why recourse to them was not particularly fruitful. However, the use of more conventional means such as the Biennale's own website and e-mail, proved more fruitful. Soon, contributors from different countries and international organizations started engaging in the process.

The value of this participation was priceless. One of the most insightful contributions, for example, was that public space is not simply for "citizens" - a traditional concept that can also be interpreted as an involuntary vehicle of exclusion (similarly to the equivocal term "community") but for all "city users", including all those who may not be necessarily welcome, such as the homeless, migrants, and "others' from the social mainstream in any given city or neighbourhood. Another one was the use of public spaces to exercise the "right of assembly", a right that is so often denied even in this supposedly inclusive age and in countries with "mature" democratic systems. Other principles were the need to conceive the design of public space keeping in mind use and maintenance factors, including the cardinal statement that the ultimate proof of success of public space is the degree of enjoyment demonstrated by the public.

The ultimate testing ground of the draft Charter was a final six-hour workshop organized at the Biennale's "final event" in May 20I3. In one of the beautifully appointed lecture rooms of the Department of Architecture of Rome's Third University (Roma Tre), the draft text of the Charter was projected on two parallel screens, one to show the Italian version, and the other to display the English one. Thus, a very diverse group ranging from UN-Habitat senior professionals to African master students from the Università "La Sapienza" was able to review all of the draft Charter's paragraphs, one by one. Workshop participants were invited to offer their contribution - to delete, to amend, to propose. The one and only rule was that all proposals had to be agreed by all to find their way in the final text.

In the end, perhaps the Charter paragraph which best defines its spirit is the following:

The Charter of Public Space aims at serving all those who believe in the city and in its extraordinary ability for hospitality, solidarity, conviviality and sharing; in its inimitable virtue in encouraging social interaction, encounter, togetherness, freedom and democracy; and in its calling for giving life to these values through public space. At the same time, cities show the worsening of economic, social, ethnic, cultural and generational inequalities. Public space must be the place where citizenship rights are guaranteed and differences are respected and appreciated.

The following day, the final versions of the Charter in Italian and English were distributed in their Italian and English versions and adopted by the Biennale's final plenary. It is worthwhile to reproduce the brief introduction to the Charter:

The following document constitutes the contribution of the Biennial of Public Space to a process of further definition on the same subject that will be conducted at the global level in collaboration with the United Nations Programme on Human Settlements (UN-Habitat), in order to make a significant contribution to the preparatory process of the third Conference United Nations on Human Settlements to be held in 2016.

During the months that followed, the Charter was presented and discussed at a number of international events, including the first two "Future of Places" international conferences in Stockholm and Buenos Aires, and the 2014 World Urban Forum in Medellin. Pocket versions of the Charter were distributed at major urban fora, to be followed by a version in eight languages printed in 2016.

I 58 | The Journal of Public Space, 2(I), 20I7| ISSN 2206-9658

(C) Queensland University of Technology 
But the most important follow-up action was the agreement of collaboration signed between UN-Habitat and Italy's National Institute of Planning (INU) at the very same edition of the Biennale. This led to an international Expert Group Meeting on Public Space and Sustainable Urban Development in January 2014, which laid the foundation for the "Global Public Space Toolkit" that UN-Habitat had decided to compile within the framework of its global public space programme. INU was contracted to partner UN-Habitat in the drafting of the Toolkit, which took the form of some sort of "validation" of the Charter by coupling its principles to examples of public-space good practices from all over the world. Like the Charter, the Toolkit is downloadable from the UN-Habitat Urban Gateways website (http://www.urbangateway.org).

By far the most important development in terms of universal acceptance of the importance of public space for sustainable urban development was its inclusion as one of the targets of Sustainable Development Goal \#II adopted by the UN General Assembly in September 2016:

By 2030, provide universal access to safe, inclusive and accessible, green and public spaces, in particular for women and children, older persons and persons with disabilities.

What is extraordinary about this commitment is that it goes far beyond what the Charter and/or other universal statements on public space ever ventured to suggest. By endorsing this target, all States agreed to pursue this objective, and indeed to be subject to monitoring mechanisms to gauge its implementation. However, what will we be supposed to measure? This is why the Charter, together with the Toolkit, has now become one of the instruments that can facilitate the attainment of the SDG Public Space Target. But how to do it? First of all, we need to define what are the public spaces SDG II pledges to ensure universal access to. And since neither the SDG construct nor the New Urban Agenda adopted in Quito contain such definition, we can seek help from the definition contained in the Charter and endorsed by the Global Public Space Toolkit:

Public spaces are all places publicly owned or of public use, accessible and enjoyable by all for free and without a profit motive.

This definition first of all, might eliminate an element of confusion involuntarily created by the SDG target: "green and public spaces". Given that not all public spaces are green, and not all green spaces are public, we can safely assume that the SDG/PST's intention was, indeed, to refer to all public spaces, including green spaces. This assumption can open the way to a small but importance nuance contained in the Charter's definition of public space: "Public spaces are all places...". This nuance was not introduced to host the "placemaking" dimension of public space, i.e. the improbable, "instant", and often temporary elevation of "space" intended as shapeless form or meaningless two-dimensional element of the urban fabric into something enjoyable, pretty, popular, vibrant, etcetera. The "place" attribute was meant to refer to the fact that while "spaces" are generally taken to be "open" (i.e. streets, sidewalks, parks, gardens), they can also be "places" where all-important civic functions can be hosted in all weather conditions: schools, public libraries, museums, etcetera.

Another aspect of the Charter's and Toolkit's definition of public space is worth mentioning: the fact that public spaces are those, and only those, that can be accessed and enjoyed by all for free and without a profit motive. Now, trams and buses, as well as taxis could be regarded as public spaces insofar as they perform a service for the public and can be accessed by all. But while taxis do not qualify as "public spaces" since they run on a commercial basis and are not free, buses and trams also do not qualify as "public spaces" because, while often run on a non-profit basis, they are not free. They can and will become public spaces whenever an enlightened local authority will decide that since public transport is heavily subsidized anyway, it may as well become a "public good", leading to universal use, acting as an incentive to using 
private motor vehicles more sparingly, and arguably giving a decisive contribution to abating environmentally harmful and health threatening emissions. But that day may never come. Finally: the without a profit motive clause was introduced to set a boundary between genuine public space and all commercial spaces, such as malls and shopping centres, which do attract vast numbers of people albeit without an apparent obligation to buy. But malls and shopping centres are private spaces that have the authority to deny access to anyone. And nothing can substitute the right, and indeed the duty, of cities to provide free and accessible spaces to all for a variety of functions, including mobility and sports and recreation. Comforted by these definitional assists, we can now turn to the means by which the target of providing universal access to safe, inclusive and accessible, green and public spaces, in particular for women and children, older persons and persons with disabilities can be achieved. That "universal", in primis. This term, in UN parlance, is meant to refer to "everywhere" (i.e. all countries, all kinds of settlements) and "everybody": rich and poor, healthy and ill, fortunate or not. The Public Space Toolkit emphasizes that public space, precisely because it is exempt from the laws governing private goods, can be a way to accommodate the needs of those who do not have the means to secure needed space and services. It is, in other words, a means to help improve equality in cities. The problem is, as the Toolkit also notes, that public space themselves are distributed inequitably in cities. Typically, low income neighbourhoods have less public space than wealthier ones; and these public spaces are, as a rule, less secure and less well kept than the others. Hence, the safety, inclusiveness and accessibility parameters must be measured not simply in terms of individual public spaces (how safe, inclusive and accessible is my park, my sidewalk) but also in broader, city-wide terms. A great park in the central part of the city can be inaccessible and not very inclusive if less fortunate city dwellers have to travel a very long way and perhaps at unreasonable expense to enjoy it alongside nearby residents. This is why the Toolkit proposes to measure public space in cities in aggregate terms but with the use of "quadrants" in order to be able to capture inequities in different parts of the city in terms of per capita availability of different kinds of public spaces.

The fourth Biennial of Public Space (BISP 2017 - http://www.biennalespaziopubblico.it/) will be held in Rome on May 25-27th, at University of Roma TRE, Testaccio neighbourhood. It will be the first one held after the adoption of the Sustainable Development Goals and the New Urban Agenda. Therefore, it will have the opportunity to take stock of the challenges the two events posed to city dwellers, civil society and policy makers.

If it will limit itself to parading good practices and admirable projects it will miss this opportunity. However, the intention is to lend an attentive ear, as always, to the work of international agencies and organizations. In fact, one of the preparatory activities proposed is to activate a dialogue paying special attention to the role that local governments and an efficient and responsible public sector can perform in addressing the SDG Public Space Target, and their unique civic responsibility and development potential: policies and planning. Unless this role is explored and enabled, it is highly unlikely that the SDG public space target will be achieved simply relying on civil society initiatives, isolated good practices and spirited performances.

\section{To cite this article:}

Garau, P. (2017). The Biennial of Public Space in Rome. From the Charter of Public Space to the post-Habitat III Agenda, The Journal of Public Space, 2(I), I57-I60, DOI: I0.5204/jps.v2i I.59

This article has been accepted for publication in The Journal of Public Space. Please see the Editorial Policies under the 'About' section of the journal website for further information.

This work is licensed under a Creative Commons Attribution - Non Commercial 4.0 International License. https://creativecommons.org/licenses/by-nc/4.0/

160 | The Journal of Public Space, 2(I), 20I7| ISSN 2206-9658

(C) Queensland University of Technology 